\title{
The Best Interests of the Child in Cases of Migration
} Assessing and Determining the Best Interests of the Child in Migration Procedures

\section{Margrite Kalverboer}

Department of Special Needs Education and Youth Care, University of Groningen, The Netherlands

m.e.kalverboer@rug.nl

\section{Daan Beltman}

Study Centre for Children, Migration and Law, Department of Special Needs Education and Youth Care, University of Groningen, The Netherlands d.beltman@rug.nl

\section{Carlavan $\mathrm{Os}$}

Study Centre for Children, Migration and Law, Department of Special Needs Education and Youth Care, University of Groningen, The Netherlands e.c.c.van.os@rug.nl

\section{Elianne Zijlstra}

Study Centre for Children, Migration and Law, Department of Special Needs Education and Youth Care, University of Groningen, The Netherlands a.e.zijlstra@rug.nl

\footnotetext{
Abstract

The best interests of the child principle has a legal base in the United Nations Convention on the Rights of the Child. In 2013, the United Nations Committee on the Rights of the Child published guidelines on the implementation of the best interests of the child in General Comment No. 14. Together with the Best Interest of the Child Method, which is developed by Zijlstra et al. (2012), this framework offers a valuable tool for decision-making processes concerning children, in particular, in this review's context, in migration procedures. In the assessment of the best interests of children who are forcibly migrated, special attention has to be given to risk factors associated with the different phases in the migration process that may harm their mental health, 
the involvement of professionals who have knowledge of children's mental health and development.

\section{Keywords}

best interests of the child - UNCRC General Comment No. 14 - implementation of the UNCRC - decision-making - BIC-assessment - BIC-determination - migration mental health - well-being - development

The Convention on the Rights of the Child (CRC) gives children the right to have their best interests assessed and weighted as a primary consideration when decisions concerning them are made. ${ }^{1}$ This principle is important for children involved in migration procedures because it means that decisions concerning either their admission to a host country or their return to a home country $^{2}$ should show their best interests being the first priority.

Children are a vulnerable group of people (Biggs and Jones, 2014; Herring, 2012). Children involved in migration procedures can be regarded as even more vulnerable as migration in itself may have a negative impact on the health, development and well-being of children (Abebe et al., 2014; Belhadj et al., 2014). Children who are forced to leave their home country due to war or other forms of violence run an increased risk because of the stressful events they may have encountered before and during the flight and the uncertainty about their new home and future perspectives (Bronstein and Montgomery, 2011; Fazel et al., 2012; Van Os et al., 2016). When they enter a host country with their parent(s), guardian or as an unaccompanied minor in search of protection, they may have suffered persecution, starvation, (sexual) violence, war etc. in their home country, in the country they came from and/or on their flight. Many of them cope with (multiple) mental health issues, e.g. post-traumatic stress, anxiety, fear and/or depressions (Henley and Robinson, 2011; Heptinstall et al., 2004;

1 Article 3, para. 1, CRC: 'In all actions concerning children, whether undertaken by public or private social welfare institutions, courts of law, administrative authorities or legislative bodies, the best interests of the child shall be a primary consideration'.

2 In this review, in order to be consistent, we use the term "home country", however we have to remark that in some cases it could occur that the migrant child who is not allowed to stay in a host country must return to a "country of origin" which is not always a "home country". 
Montgomery, 2011). These mental health issues create a need for extra attention and care in the determination of their best interests and require knowledge about what children need, about children's psychology and development. In order to safeguard the best interests of migrant children during their procedures, it is important to have science-based standards for determining and assessing the best interests of the child (Kalverboer, 2014).

This review shows how the Best Interests of the Child (BIC) Model provides such a standard. The BIC-Model focuses on the rearing conditions of children in their family life and in the societal context and has proven to be a useful model to describe the best interests of the child for asylum-seeking children in the Netherlands (Kalverboer and Zijlstra, 2006; Zijlstra, 2012). The different aspects of the BIC-Model are reflected in the guidelines of the United Nations Committee on the Rights of the Child, published in General Comment No. 14 (GC No. 14). These guidelines provide the worldwide accepted standard about what is meant by the best interests of the child concept and how this concept should be applied.

This conceptual review starts with an overview of the legal framework of the best interests principle, followed by a description of GC No. 14 and the BICModel. We apply this theoretical framework to a best interests assessment for children involved in asylum procedures, paying special attention to their vulnerabilities and illustrate this with a case study. We conclude this review with a discussion about the need for the implementation of the assessment and determination of the best interests of the child in accordance with the CRC and how this could be realised in practice.

\section{The Legal Framework of the Best Interests of the Child Principle}

\subsection{The United Nations Convention on the Rights of the Child}

In 1989, the United Nations adopted the CRC. This international multilateral treaty has been signed and ratified by almost all the countries in the world. ${ }^{3}$ The purpose of the CRC is to safeguard the well-being of children by providing them with independent rights. States that have signed and ratified the CRC are legally bound by the content of the treaty which defacto means that they have to refrain from acting in contravention of the CRC and that they have to strive for the implementation of the CRC in the domestic legal orders (Lundy et al., 2013; Kilkelly, 2011).

3 See http://indicators.ohchr.org/: Only the United States of America did not ratify the Convention. 
The CRC provides a child rights framework for assessing the status of migrant children (Pobjoy, 2013). The CRC contains four guiding principles which all interrelate with each other and with the CRC's other provisions. These are Article 2, the non-discrimination clause, Article 6, the right to life and development, Article 12, the right to be heard and last but not least, Article 3, the best interests of the child principle. As it is internationally the most recognised, Article 3, CRC is the best interests of the child umbrella provision safeguarding the best interests of the child in all kinds of decision-making procedures that involve children (Zermatten, 2013; Freeman, 2007; Verhellen, 2000). For migrant children Article 2, CRC is highly important because it protects them from discrimination in exercising their rights as described by the CRC on grounds of their legal status. This means that migrant children who do not (yet) have a residence permit also have equal rights compared to national children. Moreover, Article 22, CRC provides asylum-seeking and refugee children the right to appropriate protection.

The implementation of CRC obligations and principles in the context of migration is supported by an underlying principle: that the standards set out by the CRC should have primacy over any other aspect or policy involved. One of the implications is that children's rights should never be subjected to migration goals defined by a state. In other words, children's rights should be explicitly included in any migration policy, piece of legislation, and decision that might impact them (Ceriani Cernadas, 2015).

Supervision of the implementation of the CRC has been assigned to the United Nations Committee on the Rights of the Child. The Committee's primary tasks consist of monitoring the CRC's implementation process in the States, issuing recommendations which point out the States Parties' shortcomings in the implementation of the CRC, considering individual complaints alleging violations of the Convention on the Rights of the Child and drawing up general comments which provide detailed explanations on how specific CRC provisions have to be interpreted and implemented (Doek, 2011).

\subsection{The Best Interests of the Child Principle in EU Law}

The EU as a non-state actor cannot become a party to the CRC but that does not mean the instrument has no force at Eu level. According to the general principles of $\mathrm{EU}$ law, ${ }^{4}$ the $\mathrm{EU}$ must adhere to the principles and provisions set out in international human rights law in relation to those matters that fall

4 The written and unwritten principles drawn from the common, constitutional traditions of the Member States (see Article 6 Treaty on European Union). 
within the scope of EU competence (Stalford, 2015). In this review, the EU legal context serves as a good example of how international legal concepts can be directly applied at regional and domestic level. For the legal strength of the best interests of the child principle, this has proven to be of utmost importance in the Eu Member States ( $c f$. Stalford, 2015).

From a worldwide perspective, the law of the European Union is a unique regional law system as it has in many cases direct impact on the domestic legal orders of 28 European Member States. Another unique fact is that there is no other regional law system in the world with such an impact ( $c f$. Lenaerts et al., 2014:1) that includes the best interests of the child principle in so many different regulations ( $c f$. Stalford, 2015; Stalford and Drywood, 2011). The Eu human rights framework is mainly covered by the EU Charter of Fundamental Rights (Charter) (De Vries et al., 2013), which includes a provision on the best interests of the child, namely Article 24 of the Charter. This provision is, according to the Explanations relating to the Charter (European Union, 2007), directly based (among other CRC provisions) on Article 3 of the CRC.

In addition to the Charter, the best interests of the child principle can be found in several EU legal instruments, such as EU Regulations and EU Directives. The EU Regulations and EU Directives that are specifically focused on the issue of asylum and immigration, constitute the Common European Asylum and Immigration Policy (Hailbronner, 2013). The best interests of the child principle can be found, for example, in Article 6 of the Dublin Regulation (604/2013); Article 23 of the Reception Directive (2013/33/EU); Article 5 of the Family Reunification Directive (2003/86/EC); Article 20 of the Qualification Directive (2011/95/EU); Article 25 of the Procedures Directive (2013/32/EU); and Article 5 of the Return Directive (2008/115/EC).

The Charter ${ }^{5}$ as well as these instruments are either directly ${ }^{6}$ or indirectly ${ }^{7}$ applicable in the Member States' domestic legal orders (Chalmers et al., 2014). As Article 24 of the Charter is based on Article 3 of the CRC, we argue that the best interests of the child principle should be determined in accordance with GC No. 14. Moreover, also within the specific context of the Common European Asylum and Immigration Policy, the best interests of the child principle as enshrined in the EU Regulations and Directives should be

5 Article $5^{1}$ of the Charter: 'The provisions of this Charter are addressed ... to the Member States only when they are implementing Union law. They shall therefore respect the rights, observe the principles and promote the application thereof in accordance with their respective powers'.

6 As it concerns EU Regulations.

7 As it concerns EU Directives. 
determined in accordance with the GC No. 14. To date, the European Court of Justice has not yet established this link but may do so in the near future when this Court starts embracing the CRC more fully (Stalford, 2015).

\subsection{The Legal Status and Function of Gc No. 14}

By signing and ratifying the United Nations human rights treaties, States Parties also recognised the power of United Nations human rights treaty bodies, such as the United Nations Committee on the Rights of the Child, to draw up general comments. A general comment is an authoritative political and moral instrument with a degree of legal weight that supports the implementation process and the interpretation of specific treaty provisions. The legal weight conferred on general comments regards the implementation of one of the treaty provisions in the (legal) context of a specific case (Human Rights Committee, 1981; Craven, 1998; Otto, 2002; Keller and Grover, 2012; Gerber et al., 2013).

With regard to GC No. 14 providing guidance on how to implement the best interests of the child principle as enshrined in Article 3, para. 1, CRC, States Parties are thus politically and morally bound by the content of GC No. 14 . Therefore GC No. 14 should be taken as a primary starting point for the implementation and interpretation of Article 3, para. 1, of the CRC and Article 24 of the Charter.

The Best Interests of the Child-Model as an Integrated Part of General Comment No. 14

This paragraph describes the general theoretical framework of the assessment and determination of the best interests of the child, as drawn up in GC No. 14 of the United Nations Committee on the Rights of the Child and the B IC-Model. We also show that the BIC-Model is reflected in the guidelines of GC No 14.

\subsection{Best Interests of the Child Assessment and Determination}

Summarising, it follows from GC No. 14 that the best interests of the child assessment and determination should take place in a very systematic way for which two steps should be followed ( $c f$. Pobjoy, 2015). First, within the specific factual context of the case one has to find out what the relevant elements in a best-interests assessment are, give them concrete content, and assign a weight to each in relation to another (GC No. 14, para. 46). Secondly, to do so, a procedure that ensures legal guarantees and proper application of the right should be followed (GC No. 14, para. 46). In the best-interests assessment one needs to 
bear in mind that the purpose of assessing and determining the best interests of the child is to ensure the full and effective enjoyment of the rights recognised in the CRC. In addition, states must create an environment that respects human dignity and ensures the holistic development of every child (GC No. 14, para. 42; 82) ( $c f$. Barnes, 2012). Assessing the child's best interests is a unique activity, which should be undertaken in each individual case, in the light of the specific circumstances of each child or group of children in general. These circumstances relate to the individual characteristics of the child or children concerned as well as the social and cultural context of the child. Determining what is in the best interests of the child should start with an assessment of the specific circumstances that make the child unique (GC No. 14, paras. 46$49 ; 80-83$ ). Decision-makers should not only assess the physical, emotional, educational and other needs at the specific moment of the decision, but also should consider the possible scenarios of the child's development, and analyse them in the short and long term. In this context, decisions should reflect the continuity and stability of the child's present and future situation (GC No. 14, para. 84). To sum up the specific elements which should be taken into consideration in the assessment:

1. The child's views (GC No. 14, paras. 53-54);

2. The child's identity (sex, sexual orientation, beliefs, cultural identity, personality) (GC No. 14, paras. 55-57);

3. Preservation of the family environment and maintaining relations with the family and preservation of the ties of the child in a wider sense. These ties apply to the extended family as well as friends, school and the wider environment (GC No. 14, paras. $5^{8-70}$ );

4. Care protection and safety of the child (GC No. 14, para 71-74);

5. The child's vulnerability (GC No. 14, paras. $75^{-76}$ );

6. The child's right to health (GC No. 14, paras. $77-78$ );

7. The child's right to education (GC No. 14, paras. 79).

\subsection{Procedural Safeguards}

The formal assessment process should be carried out in a child-friendly safe atmosphere. The characteristics and needs of the child should be assessed by professionals who have expertise in child and adolescent development and who are trained in, inter alia, child psychology, child development and/ or other relevant human and social development fields. Moreover, these professionals should have experience working with children and be capable of considering information received in an objective manner. As far as possible, a multidisciplinary team of professionals should be involved in assessing the child's best interests (GC No. 14, para. 94). 
The child's views should be taken into account and due weight according to their age and maturity should be given to these ( $c f$. Archard and Skivenes, 2009). Communicating with the child, informing the child about the process and possible sustainable solutions and services as well as collecting information from children and seeking their views are vital (GC No. 14, paras. 53-54). Any decision concerning the child must be motivated, justified and explained. If, exceptionally, the solution chosen is not in the best interests of the child, the grounds for this must be set out in order to show that the child's best interests were a primary consideration despite the result (GC No. 14, para. 97). The child will need appropriate legal representation and there should always be the possibility to request a review or to appeal against a decision which seems not to be in accordance with the appropriate procedure of assessing and determining the child's or children's best interests (GC No. 14, paras. 96; 98).

\subsection{The Best Interests of the Child-Model}

The 14 rearing conditions of the BIC-Model together represent the social and cultural context the child grows up in (see Annex 1). If the rearing conditions of the BIC-Model are of a sufficient high quality over an extended period, there will be continuity and stability in the child's life; the child will be able to develop in a positive way (GC No. 14, para. 84). If the conditions are of an insufficient quality over an extended period, this may harm the child's development and his or her experience of childhood; the child's identity will be threatened (GC No. 14, paras. 55-56). This applies in particular to vulnerable children. The rearing environment of vulnerable children should meet extra high criteria (GC No. 14, paras. 75-76). In order to experience a good childhood and to develop in a positive way, the child needs a social and cultural context which provides opportunities to do so. Good education, social bonds, ties with family and significant others, safety and respect for the child's individuality are essential (GC No. 14, paras. 48; 58-70; 71-74).

Annex 1 describes the BIC-Model including the 14 environmental conditions for development with references to corresponding CRC articles and the paragraphs of GC No. 14 reflecting these conditions.

How the Child's Best Interests can be Assessed and Determined in the Asylum Procedure

The Study Centre for Children, Migration and Law of the University Groningen (Study Centre) brings the BIC-Model into practice by using the accompanying Best Interests of the Child- Method in individual cases concerning children involved in migration procedures (Kalverboer et al., 2011), which comes down to a 
BIC assessment and determination. The BIC-Method is compiled of, inter alia, an interview, based on the conditions of the BIC-Model; the BIC-Questionnaire for professionals to assess the child's current environment in order to compare it with the situation, which can be expected to arise if the child remains in or leaves the host county (GC No. 14, para. 84) (Zijlstra et al, 2012; Zijlstra, 2012); and a BIC-Selfreport which reflects the child's own views on his or her rearing environment at the moment; when he or she would remain in the host country or would return to the home country (GC No. 14, paras 43-44; 89) (Ten Brummelaar et al., 2014). To assess the best interests of asylum-seeking children, the university works together with lawyers who represent the child or children in migration procedures. Lawyers make a request at the Study Centre to conduct a BIC assessment and determination. At the Study Centre the request is being processed. Then, by way of the BIC Method, the assessment and determination is done by child psychologists who interview the child and family members and who ask them to complete several questionnaires. In addition to the family, information is collected from other informants who are in contact with the child on a regular basis like teachers and care workers, guardians or therapists (GC No. 14, para. 92). In asylum cases, the history of the child in the home country, related to his or her vulnerability and social and emotional development, is always part of the assessment (Van Os et al., 2016) as well as the child's prospective situation as regards safety and the expected continuity and stability in the child's future life circumstances if the child would return to the home country (Kalverboer et al., 2009; Zijlstra et al., 2012; Zijlstra, 2012) (see Annex 2).

The elements involved in the assessment of the vulnerability of the child are based on scientific research. These studies revealed risk factors for the mental health of refugee children associated with the periods before, during and after the migration (Kalverboer, 2014). Specific events before the flight, which correlate with higher scores on Post Traumatic Stress Disorder (PTSD) (Heptinstall et al., 2004), are separation from parents (Bean et al., 2007, Hodes et al., 2008; Hollins et al., 2007), being exposed to violence and the violent death of a family member in the home country (Geltman et al., 2005). Several studies state that violence against one of the parents is a risk factor for children's mental health (Almqvist and Brandell-Forsberg, 1997; Montgomery and Foldspang, 2006; Sujoldzic et al., 2006). Experiencing violence during the migration constitutes an additional risk to children's mental development (Berthold, 1999; Cohn et al., 1985; Sujoldzic et al., 2006). Children who flee alone are exposed to additional risks; girls are even more vulnerable. Hardship during the migration, danger and a long duration of the migration are additional risk factors (Fazel et al., 2012). During their residence in the host country many refugee children have social and emotional problems and grow up 
in rearing environments of poor quality. Continuity and stability are missing in their lives (Kalverboer and Zijlstra, 2006; Kalverboer and Zijlstra, 2008; Zijlstra, 2012; Kalverboer et al., 2009). There is a relationship between the uncertainty these children experience because of the judicial proceedings in which they are involved and depressions, social and emotional problems (Fazel et al., 2012). Experiences of discrimination (Ellis et al., 2008; Montgomery, 2008; Sujoldzic et al., 2006) also form a risk factor for the children's mental health. Frequent changes in their place of residence are also referred to as risk factors (Bean et al., 2007; Nielsen et al., 2008). The studies by Heptinsall et al. (2004) and Ellis et al. (2008) show a direct relationship between stress after migration and higher PTSS scores. There is also a direct relationship between stress after migration and depression (Heptinsall et al., 2004). The forced return of asylum-seeking children to their home country after a period of five years is harmful to their mental health (Kalverboer et al., 2009).

In the assessment of the best interests of asylum-seeking children, the Study Centre pays specific attention to the above risk factors, especially in the assessment of the child's vulnerability.

Following the BIC assessment and determination a social welfare report is drawn up with an expert opinion on the best interests of the child. In the social welfare report an indication is given of the consequences of the decision taken during the asylum procedure and of the alternative that best serves the holistic development of the child in the short and long term. The child's opinion as to the best solution and the children's rights that are violated in the available alternative solutions are also described.

With reference to the decision-making rules based on the key articles of the CRC and GC No. 14, the solution that offers the child the best guarantees for a safe, healthy and adequate development is the one to be chosen if the child's best interests would be paramount (GC No. 14, paras. 43-44; 84). This solution is included and recommended in the social welfare report. As in all decision-making procedures, there are other interests involved ( $c f$. Eekelaar, 2015), in the case of migration, for example, the State's interests to control the immigration influx. In the determination process, it is the task of the migration authorities to balance those interests. Procedural guaranties have to ensure that the assessment and determination is correctly implemented (GC No. 14, paras. 85-87). Practising the BIC-Method and following the guidance of GC No. 14, would offer a great chance to asylum-seeking children that their request for protection is dealt with in a systematic, fair, professional, independent, children's-rights-proof and science-based way. A case-study by Beltman et al. (2016) shows some preliminary conclusions on the legal effect of the submission by lawyers of the social welfare reports as expert opinions in judicial proceedings. 
We now show an example of how the child's best interests could be assessed in a particular decision-making procedure by applying the BIC-Method to the case of an Afghan girl, L., and her Azerbaijani mother, Ms. A. (Kalverboer, 2014). The family's lawyer requested the University of Groningen Study Centre for Children, Migration and Law to conduct an assessment on the development and prospects of the girl and to write a social welfare report on her case. The report states which decision is in the best interests of L.'s development and what L. herself thinks about this. The family's lawyer intended to submit the report in the legal proceedings so that the girl's best interests could be considered when the decision was made.

To find out more about the lives of L. and her mother, an assessment was carried out by a child psychologist and a child psychiatrist. L. was 14 years old when we first saw her. At that point she had already been residing in the Netherlands for almost eight years. In conversations with the mother and daughter together and with the daughter separately, information was gathered about the quality of L.'s rearing environment in the Netherlands and in her home country, about her development, vulnerability and resilience. We additionally used questionnaires to find out more about L.'s development and problems that were completed by L. herself, by her mother and by L.'s teachers. We gained information from care workers and used information about the situation in Afghanistan with regard to children's rights and human rights. Both the childrearing specialist and the child psychiatrist then wrote a report. To come to a good assessment one needs to know about the child's history, the current situation and the prospects in case of returning to the home country. Only with information on all these aspects a recommendation can be made regarding the decision that serves the child's best interests.

\section{L's life before the migration}

The parents of L. (girl, 14 years old) met each other during their studies in Azerbaijan. Her mother had Azerbaijani nationality and her father Afghan. When Ms A. was 19 years old, she left her home country in order to live with her husband and his family. She says that at first life in Afghanistan was not easy, but that she was able to fit in quite well. L. was born when Ms A. was 23 years old. L. spent the first six and a halfyears of her life in Afghanistan and was brought up by her mother and grandmother. She lived in a big house with a big garden. Although their relationship was good, there were often differences of opinion between Ms A. and her Afghan in-laws about how L. should be cared for and brought up. This led to inconsistencies in the way 
they approached L. Nevertheless, there was a warm affective climate and L. felt safe. This changed when her grandmother died. L. was then six years old. Apart from her mother, her grandmother was the most important figure in her upbringing. When L. was six and a half years old, her father was murdered. Her mother then fled with L. to the Netherlands

\subsection{Risk Factors for Development in the Home Country}

Looking at L's history in the home country, it appears that there is an accumulation of risks for vulnerability which we also found in the academic literature on mental health risks (see Annex 2) such as the lack of safety in the country, the death of her grandmother and the violent death of her father. Table 1 shows that with regard to L.'s situation in Afghanistan before the awful events took place, the quality of only five conditions of the BIC-Q was diagnosed as adequate. Seven conditions were of inadequate quality and two conditions were not assessed because there was insufficient information to come to a reliable assessment.

\subsection{Risk Factors for Development during the Flight}

Table 1 shows that there is insufficient information available to make a reliable assessment of the quality of L.'s rearing during the flight. The story of the flight is characterized by secrets and traumatic events we were not able to talk about.

\section{L's life in the host country}

Since arriving in the Netherlands, L. and her mother have lived in many different places. There have been times when she and her mother slept on the streets. L. has often changed schools. For the past $7^{1 / 2}$ years she has not known if she will be going to the same school or living in the same house the next day or if she will be picked up and expelled. L. has serious behavioural problems at home and at school; she has compulsions and obsessions, and a very negative self-image. At school the teachers and children do not know about the circumstances in which she is growing up. As a result, her behaviour is interpreted as 'just very challenging' and it is increasingly difficult for her to cope at school. She is often sent out of class because she cannot control herself. Her life is dominated by stress and repressed fear. Her mother cannot provide for a safe environment for her because of her own psychiatric problems.

\section{$5 \cdot 3$} Risk Factors for L's Development in the Host Country

The report presents a picture of a girl with severe behavioural and emotional problems. Again we find risk factors for the developmental problems of $\mathrm{L}$. 


BIC-Model's environmental conditions Afghanistan* Flight $^{*}$ Netherlands*
for development

1. Adequate physical care

2. Safe immediate physical environment

$\begin{array}{lll}1 & ? & 1 \\ 1 & ? & 1 \\ 1 & ? & 0 \\ ? & 0 & 1 \\ ? & ? & 0 \\ 1 & ? & 0 \\ 0 & 0 & 0\end{array}$

3. Affective atmosphere

4. Supportive, flexible parenting structure

5. Adequate example set by parents

6. Interest in the child

7. Continuity in upbringing and care, future perspective

8. Safe wider physical environment

9. Respect

$\begin{array}{lll}0 & 0 & 1 \\ 0 & ? & 0 \\ 1 & ? & 0 \\ 0 & ? & 1 \\ 0 & ? & 1 \\ 0 & ? & 1 \\ 0 & & \\ & & 0 \\ 5 & & 7\end{array}$

* $1=$ adequate, $0=$ inadequate, ?=unknown

which are also found in the academic literature, for instance the lack of continuity and stability in L's life and her long stay in the host country (see Annex 2). The child psychiatrist concludes that there are psychiatric problems which are related to the circumstances in which L. is growing up and her uncertain legal residence status. The quality of her rearing environment in the Netherlands is assessed as inadequate (see Table 1).

\subsection{Re-assessment}

L. and her mother had their first interview in 2009. They were re-examined twice. In October 2012 - when the last interview took place - L. was doing a bit better. She had done a work placement in a clothing shop and had really enjoyed it. During the hours of her work placement she was able to control her compulsions, though they returned when she went home. 


\subsection{The Decision in the Case of $L$.}

Based on the first assessment in 2009, the Dutch Immigration and Naturalisation Service $(I N D)$, the authority that makes the decisions upon requests for a residence permit, decided that $\mathrm{L}$. would be given a residence-permit on medical grounds for a period of one year. She had to be re-examined every following year. If she had had a right of residence on medical grounds for three consecutive years she could claim a more permanent right of residence. The slight improvement in 2012 therefore reduced her chance of a permanent right of residence. In mid-August 2013, it turned out that she was eligible to claim a residence status based on a special Dutch regulation for long-term residing migrant children, the Amnesty for Children. In her own words, L. was then 'finally able to start her life'.

\section{Concluding Remarks and Discussion}

Children who are forced to leave their home country due to war or other forms of violence run an increased risk of suffering mental health problems because of the stressful events they may have encountered before and during the flight and the uncertainty during their residence procedure. According to Article 3 , CRC (and Article 24 of the Charter), decisions in migration procedures should be based on the best interests of the child, taking into account the diverse vulnerabilities migrant children may face.

With the publication of GC No. 14, the United Nations Committee on the Rights of the Child made clear what the drafters of the CRC must have meant by this principle and how it should be implemented. We described how this best interests principle also applies to children in migration procedures and how the assessment and determination of the best interests should then be carried out.

Everyone dealing with children as part of their daily activities or only on occasions, such as social workers, youth care professionals, policy officers, legal decision-makers, judges, general practitioners, psychiatrists and so forth should take due notice of the principles set out in GC No. 14. It is essential that GC No. 14 is implemented at the level of national legislation as well as in policy and practice as in work instructions or in work guidelines. Negligence in the implementation of the best interests of the child principle could lead to the violation of fundamental children's rights, which should be prevented at all costs, as it runs against the very existence and purpose of the CRC to which States parties are politically, morally and legally bound. 
The BIC-Model is based on academic knowledge and is reflected in GC No. 14. Academic knowledge is essential for deciding which of the relevant elements are to be part of the best interests of the child assessment, the content of these elements and how they should be weighted. The BIC-Method can be used as a tool in the assessment and determination of the child's best interests in all kinds of legal and other decision-making procedures, including cases of migration, in which the quality of the child rearing - the social and cultural context the child grows up in - is at stake. In a case of migration it is especially important that professional care is taken in assessing the best interests of the child because one of the consequences of the decision might be the expulsion of children leading to a possible deterioration of the child's development.

Expert knowledge is needed to assess the relevant elements of the child's best interests such as the vulnerability and the quality of the rearing conditions of the child as summarised in the BIC-Model. Following GC No. 14, the migration authorities who decide about the request of a child seeking protection are responsible for assessing and determining the best interests of the child affected by their decisions and have to show how the child's interests are weighted against other interests (GC No. 14, para. 6 (c)). In migrant cases, the best interests of the child is generally weighted against the interests of the State to control the migration influx. In the daily practice of the University of Groningen Study Centre for Children, Migration and Law we often see that migration policy arguments overweigh the best interests of the child (Beltman and Zijlstra, 2013). This practice can be observed in other Western countries too (Feijen, 2009; Eastmond, 2011; Shamseldin, 2012). Bhabha (2014) calls the 'children's battle for refugee protection' one of David and Goliath. She stresses that the child itself - we would add: or his or her parents - made a thorough best interests assessment before the decision was taken to flee the country (Bhabha, 2014: 204). This observation underlines the importance of including the views of the child in the best interests assessment, as prescribed by GC No. 14 (paras. 53-54) and as stipulated by Article 12 of the CRC. For accompanied children the views of the parents also provide indispensable information, as we described in the BIC-Method. Looking at unaccompanied minors, special attention and weight should be given to the views of the guardian, the person who is actually appointed to defend the child's interests (Arnold et al., 2014). However, including the views of the child, parents or care givers and the guardian does not reduce the tension that exists between the interests of States to control migration and a fair and professional best interests of the child assessment and determination. The United Nations Committee on the Rights of the Child addresses this issue in another context: in situations where the child's views are in conflict with the parents' views, a separate representation 
for the child should be established (GC No. 14, para. 9o). Migration authorities by definition have to deal with almost always conflicting fields of interests: those of the child and the State. If the parents of the unaccompanied child are still alive, efforts should also be made to contact the parents of the unaccompanied child in the home country or elsewhere.

Finally, as we have shown in this review, academic knowledge about child psychology, development and child rearing is necessary to come to a good assessment. As in situations where children and their parents have different views or even interests, we think in decisions in migration law context it is in the best interests of the child to have an independent expert's opinion about which decision would protect the safety, well-being and development of the child most. Perhaps an independent council or institute in which child-rearing specialists and child psychologists work could conduct such assessments. These independent and professional assessments of the best interests of asylum-seeking children would help the migration authorities to fulfil their obligation to determine the best interests of the child and give these priority in their decisions. By doing so, states would comply with the CRC, in particular with the four guiding provisions of the CRC: and prevent possible children's rights violations.

\section{References}

Abebe, D., Lien, L. and Hjelde, K., "What We Know and Don't Know About Mental Health Problems Among Immigrants in Norway",Journal of Immigrant and Minority Health 2014 (16(1)), 60-67. DoI: 10.1007/s10903-012-9745-9.

Almqvist, K. and Brandell-Forsberg, M., "Refugee children in Sweden: Post-traumatic stress disorder in Iranian preschool children exposed to organized violence", Child Abuse and Neglect 1997 (21(4)), 351-366. Dor: 10.1016/So145-2134(96)oo176-7.

Archard, D. and Skivenes, M., "Balancing a Child's Best Interests and a Child's Views", International Journal of Children's Rights 2009 (17(1)), 1-21. Dor: $10.1163 / 157181808 \mathrm{X}_{35} 8276$.

Arnold, S., M. Goeman. and Fournier, K., "The Role of the Guardian in Determining the Best Interest of the Separated Child Seeking Asylum in Europe: A Comparative Analysis of Systems of Guardianship in Belgium, Ireland and the Netherlands", European Journal of Migration and Law 2014 (16(4)), 467-504. DoI: 10.1163/15718166-12342066.

Barnes, A., "CRC's Performance of the Child as Developing" in M. Freeman (ed.), Law and Childhood Studies: Current Legal Issues Volume 14 (Oxford: Oxford University Press, 2012).

Bean, T.M, Eurelings-Bontekoe, E. and Spinhoven, P., "Course and predictors of mental health of unaccompanied refugee minors in the Netherlands: one year 
follow-up", Social Science and Medicine 2007 (64(6)), 1204-1215. DoI:10.1016/j. socscimed.2006.11.010.

Belhadj Kouider, E., Koglin, U. and Petermann, F., "Emotional and behavioral problems in migrant children and adolescents in Europe: a systematic review", European Child and Adolescent Psychiatry 2014 (23(6)), 373-391. DoI: 10.1007/soo787-013-0485-8.

Beltman, D., Kalverboer, M.E., Zijlstra, A.E., Van Os, E.C.C. and Zevulun, D., “The legal effect of Best Interests of the Child reports in judicial migration proceedings. A qualitative analysis of five cases" in T. Liefaard and J. Sloth-Nielsen (eds.), The United Nations Convention on the Rights of the Child: Taking Stock after 25 Years and Looking Ahead (Leiden: Brill| Nijhoff, 2016).

Beltman. D and Zijlstra, A.E., "De doorwerking van 'het belang van het kind' ex artikel 3 VRK in het migratierecht: vanuit een bottom-up benadering op weg naar een topdown toepassing (The direct effect of Article 3 CRC concerning the 'best interests of the child' in migration law: from a bottom-up approach towards a top-down implementation)", Journaal Vreemdelingenrecht 2013 (12(4)), 286-308.

Berthold, S.M., "The effects of exposure to community violence on Kmer refugee Adolencents", Journal of Traumatic Stress, 1999 (12(3)), 455-471. DoI: 10.1023/A:1024715003442.

Bhabha, J., Child Migration and Human Rights in a Global Age (Princeton, New Jersey: Princeton University Press, 2014).

Biggs, H. and Jones, C., "Legally Vulnerable. What is Vulnerability and Who is Vulnerable?" in M. Freeman, S. Hawkes, and B. Bennett (eds.), Law and Global Health: Current Legal Issues Volume 16 (Oxford: Oxford University Press, 2014).

Bronstein, I. and Montgomery, P., "Psychological distress in refugee children: a systematic Review", Clinical Child and Family Psychology Review 2011 (14(1)), 44-56. DOI:10.1007/s10567-010-0081-0.

Ceriani Cernadas, P., "The human rights of children in the context of international migration" in W. Vandenhole, E. Desmet, D. Reynaert and S. Lembrechts (eds.), Routledge International Handbook of Children's Rights Studies (London/New York: Routledge, Taylor \& Francis Group, 2015).

Chalmers, D., Davies, G. and Monti, G. (eds.), European Union Law (Cambridge: Cambridge University Press, 2014).

Cohn, J., Danielsen, L., Holzer, K.I.M., Koch, L., Severin, B., Thogersen, S. and Aalund, O., "A study of Chilean refugee children in Denmark", Lancet 1985 (326(8452)), 437438. DoI: 10.1016/So140-6736(85)92751-5.

Craven, M.C.R., The International Covenant on Economic, Social and Cultural Rights: A perspective on its development, (Gloucestershire: Clarendon Press, 1998).

De Vries, S., Bernitz, U. and Weatherill, S., The Protection of Fundamental Rights in the EU After Lisbon, (Oxford/Portland: Hart Publishing, 2013). 
Doek, J., "The CRC: Dynamics and directions of monitoring its implementation" in A. Invernizzi and J. Williams (eds.), The Human Rights of Children: From Visions to Implementation (Aldershot: Ashgate, 2011).

Eastmond, M. and Ascher, H., "The Best Interest of the Child? The Politics of Vulnerability and Negotiations for Asylum in Sweden", Journal of Ethnic and Migration Studies 2011 (37(8)), 1185-1200. DOI: 10.1080/1369183X.2011.590776.

Ellis, B.H., MacDonald, H.Z., Lincoln, A.K. and Cabrai, H., "Mental health of Somali adolescent refugees: the role of trauma, stress, and perceived discrimination", Journal Consulting Clinical Psychology 2008 (76(2)), 184-193. DoI:10.1037/0022-006X.76.2.184.

Fazel, M., Reed, R.V., Panter-Brick, C. and Stein, A., "Mental health of displaced and refugee children resettled in high-income countries: Risk and protective factors", Lancet 2012 (379(9812)), 266-282. DoI: 10.1016/So140-6736(11)6oo51-2.

Feijen, L., "The challenges of ensuring protection to unaccompanied and separated children in composite flows in Europe", Refugee Survey Quarterly 2009 (27(4)), 6373. DOI: $10.1093 / \mathrm{rsq} / \mathrm{hdno} 49$.

Freeman, M., "Article 3: The Best Interests of the Child" in A. Alen, J. Vande Lanotte, E. Verhellen, F. Ang, E. Berghmans, M. Verheyde and B. Abramson (eds.), A commentary on the United Nations Convention on the Rights of the Child (Leiden: Martinus Nijhoff Publishers, 2007).

Geltman, P., Grant-Knight, W., Mehta, S., Lloyd-Travaglini, C., Lustig, S., Landgraf, J. and Wise, P., "The 'lost boys of Sudan': functional and behavioral health of unaccompanied refugee minors resettled in the United States", Archives Of Pediatrics and Adolescent Medicine 2005 (159(6)), 585-591. DoI: 10.1001/archpedi.159.6.585.

Gerber, P., Kyriakakis, J., O’Byrne, K., “General Comment 16 on state obligations regarding the impact of the business sector on children's rights: what is its standing, meaning and effect?", Melbourne Journal of International Law 2013 (14(1)), $93^{-128 .}$

Hailbronner, K. (ed.), EU Immigration and Asylum Law. Commentary on E U Regulations and Directives (Oxford/Portland: Hart Publishing, 2013).

Henley, J. and Robinson, J., "Mental health issues among refugee children and adolescents", Clinical Psychologist 2011 (15(2)), 51-62. DoI: 10.1111/j.1742-9552.2011.00024.x.

Heptinstall, E., Sethna, V. and Taylor, E., "PTSD and depression in refugee children", European Child and Adolescent Psychiatry 2004 (13(6)), 373-380. DOI:10.1007/ soo787-004-0422-y.

Herring, J., "Vulnerability, Children, and the Law" in M. Freeman (ed.), Law and Childhood Studies: Current Legal Issues Volume 14 (Oxford: Oxford University Press, 2012).

Hodes, M., Jagdev, D., Chandra, N. and Cunniff, A., "Risk and resilience for psychological distress amongst unaccompanied asylum seeking adolescents", Journal of Child Psychology and Psychiatry 2008 (49(7)), 723-732. DOI: 10.1111/j.1469-7610.2008.01912.x. 
Hollins, K., Heydari, H., Grayson, K. and Leavy, G., "The mental health and social circumstances of Kosovan Albanian and Albanian unaccompanied refugee adolescents living in London", Diversity in Health and Social Care 2007 (4(4)), $277-285$.

Human Rights Committee, "Report of the Human Rights Committee, UN GAOR, $36^{\text {th }}$ session, Supp No 40", Un Doc A/36/40, annex VII, 29 September 1981.

Kalverboer, M.E., The best interest of the child in migration law: significance and implications in terms of child development and child rearing (Amsterdam: SWP, 2014).

Kalverboer, M.E., Zijlstra, A.E., Ten Brummelaar, M.D.C., Huyghen, A.M.N., Winter, H. and Knorth, E.J., "Children first? The significance of child-oriented social welfare reports for legal decision-making in asylum procedures", InternationalJournal of Child and Family Welfare 2011 (14(1)), 2-18.

Kalverboer, M.E. and Zijlstra, A.E., Kinderen uit asielzoekersgezinnen en het recht op ontwikkeling: Het belang van het kind in het Vreemdelingenrecht (Amsterdam: SwP Publishers, 2006).

Kalverboer, M.E. and Zijlstra, A.E., Het belang van het kind in het Vreemdelingenrecht. Kinderen uit asielzoekersgezinnen. Ontwikkeling, perspectief en juridische positie. Onderzoeksverslag periode 2006-2008 (Groningen: University of Groningen, Department of Special Needs Education and Youth Care, 2008).

Kalverboer, M.E., Ten Brummelaar, M.D.C., Post, W.J., Zijlstra, A.E. Harder, A.T. and E.J. Knorth, "The best interest of the child-questionnaire, reliability and validity: preliminary data on the question where to live after detention or secure treatment?", Criminal Behaviour and Mental Health 2012 (22(1)), 41-52. DOI: 10.1002/cbm.825.

Kalverboer, M.E., Zijlstra, A.E. and Knorth, E.J., "The developmental consequences for asylum-seeking children living with the prospect for five years or more of enforced return to their home country", European Journal of Migration and Law 2009 (11(1)), 41-67. DOI: 10.1163/1571816o9X410584.

Keller, H. and Grover, L., "General Comments of the Human Rights Committee and their legitimacy" in H. Keller and G. Ulfstein (eds.), UN human rights treaty bodies: law and legitimacy (Cambridge: Cambridge University Press, 2012).

Kilkelly. U, "Using the Convention on the Rights of the Child in Law and Policy: Two Ways to Improve Compliance" in A. Invernizzi and J. Williams (eds.), The human rights of children: From visions to implementation (Aldershot: Ashgate; 2011).

Lenaerts, K., Maselis, I. and Gutman, K., (Nowak, J.T. (ed.)), Eu Procedural Law (Oxford: Oxford University Press, 2014).

Lundy, L., Kilkelly, U. and Byrne, B., "Incorporation of the United Nations Convention on the Rights of the Child in Law: A Comparative Review", International Journal of Children's Rights 2013 (21(3)), 442-463. DOI: 10.1163/15718182-55680028.

Montgomery, E., "Trauma, exile and mental health in young refugees", Acta Psychiatrica Scandinavica 2011 (123(440)), 1-46. DOI: 10.1111/j.1600-0447.2011.01740.x. 
Montgomery, E., "Long term effects of organized violence on young Middle Eastern refugees' mental health", Social Science and Medicine 2008 (67(10)), 1596-1603. Dor: 10.1016/j.socscimed.2008.07.020.

Montgomery, E. and Foldspang, A., "Validity of PTSD in a sample of refugee children: Can a separate diagnostic entity be justified?", International Journal of Methods for Psychiatric Research, 2006 (15(2)), 64-74. DOI: 10.1002/mpr.186.

Nielsen, S.S., Norredam, M., Christiansen, K.L., Obel, C., Hilden, J., Krasnik, A., "Mental health among children seeking asylum in Denmark. The effect of length of stay and number of relocations: A cross sectional study", BMC Public Health 2008 (8), 293. DOI: 10.1186/1471-2458-8-293.

Otto, D., "'Gender Comment': Why does the UN Committee on Economic, Social and Cultural Rights need a General Comment on women?", Canadian Journal of Women and the Law 2002 (1(16)), 1-52. DoI: 10.2139/ssrn.319202.

Pobjoy, J.M., "A child rights framework for assessing the status of refugee children", in S. Juss and C. Harvey (eds.), Contemporary Issues in Refugee Law (Cheltenham/ Northampton: Edward Elgar Publishing, 2013).

Pobjoy, J.M., "The Best Interests of the Child Principle as an Independent Source of International Protection", International and Comparative Law Quarterly 2015 (64(2)), 327-363. DOI: $10.1017 /$ So020589315000044.

Presidium of the Convention, "Explanations relating to the Charter of Fundamental Rights", Official Journal of the European Union, 2007 (C 303), 17-35. http://eur-lex .europa.eu/LexUriServ/LexUriServ.do?uri=OJ:C:2007:303:0017:0035:en:PDF.

Shamseldin, L., "Implementation of the United Nations Convention on the Rights of the Child 1989 in the Care and Protection of Unaccompanied Asylum Seeking Children: Findings from Empirical Research in England, Ireland and Sweden", International Journal of Children's Rights 2012 (20(1)), 90-121. DOI: 10.1163/ 157181811 X 570717 .

Stalford, H. and Drywood, E., "Using the CRC to Inform EU Law and Policy-making" in A. Invernizzi and J. Williams (eds.), The Human Rights of Children: From Visions to Implementation (Aldershot: Ashgate, 2011).

Stalford, H., "The CRC in Litigation Under EU Law" in T. Liefaard and J.E. Doek (eds.), Litigating the Rights of the Child: Taking Stock After 25 Years of the CRC (Dordrecht/ Heidelberg/ New York/London: Springer, 2014).

Sujoldzic, A., Peternel, L., Kulenovic, T. and Terzic, R., "Social determinants of health. A comparative study of Bosnian adolescents in different cultural contexts", Collegium Antropologicum 2006 (30(4)), 703-711.

Ten Brummelaar, M.D.C., Kalverboer, M.E., Harder, A.T., Post, W.J., Zijlstra, A.E. and E.J. Knorth, "The Best Interest of the Child Self-Report Questionnaire (BIC-S): Results of a Participatory Development Process", Child Indicators Research 2014 (7(3)), 569-588. DOI: 10.1007/s12187-013-9225-3. 
United Nations Committee on the Rights of the Child. (2013). General comment No. 14 (2013) on the right of the child to have his or her best interests taken as a primary consideration (art. 3, para. 1) (CRC/C/GC/14): http://www2.ohchr.org/English/bodies/ crc/docs/GC/CRC_C_GC_14_ENG.pdf.

Van Os, E.C.C., Kalverboer, M.E., Zijlstra, A.E., Post, W.J., Knorth, E.J., "Knowledge of the Unknown Child: A Systematic Review of the Elements of the Best Interests of the Child Assessment for Recently Arrived Refugee Children", Clinical Child and Family Psychology Review 2016 (19(3)), 185-203. DoI: 10.1007/s10567-016-0209-y.

Verhellen, E., Verdrag inzake de Rechten van het Kind. Achtergronden; Motieven; Strategiën; Hoofdlijnen (Convention on the Rights of the Child. Backgrounds; Motives; Strategies; Outlines) (Leuven/Apeldoorn: Garant, 2000).

Zermatten, J., "The best interests of the child principle: literal analysis and function", International Journal of Children's Rights 2010 (18(4)), 483-499. DoI: $10.1163 / 157181810 X_{537391 .}$

Zijlstra, A.E., Kalverboer, M.E., Post, W.J., Ten Brummelaar, M.D.C. and Knorth, E.J., "Could the BIC-Q be a decision support tool to predict the development of asylumseeking children?", International Journal of Law and Psychiatry, 2012 (36(2)), 129-135. DOI: 10.1016/j.ijlp.2013.01.005.

Zijlstra, A.E., In the best interest of the child; a study into a decision-support tool validating asylum-seeking children's rights from a behavioural scientific perspective (diss.) (Groningen: University of Groningen, 2012). 
ANNEX 1

\title{
Best Interests of the Child (BIC-) Model including the 14 Environmental Conditions for Development with References to Corresponding CRC Articles and the Paragraphs of Gc No. 14 Reflecting These Conditions
}

\author{
Family: Current Situation
}

\section{Physical Wellbeing}

1. Adequate physical care (Arts. 24, 26, 27 CRC; GC 14 paras. 70, 71, 77, 78, 84)

Adequate physical care refers to the care for the child's health and physical wellbeing by parents or care-providers. They offer the child a place to live, clothing to wear, enough food to eat and (some) personal belongings. There is a family income to provide for all this. In addition, the parents or care-providers are free of worries about providing for the child's physical well-being.

2. Safe immediate physical environment (Art. 19, 24 CRC; GC 14 paras. 61, 70, 71, 73, 74, $77,78,84)$

A safe direct physical environment offers the child physical protection. This implies the absence of physical danger in the house or neighbourhood in which the child lives. There are no toxics or other threats in the house or neighbourhood. The child is not threatened by abuse of any kind.

\section{Care and Upbringing}

3. Affective atmosphere (Art. 19 CRC; GC 14 paras. 70, 71, 72, 84)

An affective atmosphere implies that the parents or care-providers of the child offer the child emotional protection, support and understanding. There are bonds of attachment between the parent(s) or care-giver(s) and the child. There is a relationship of mutual affection.

4. Supportive, flexible parenting structure (Art. 13, 14 CRC; GC 14 paras. 70, 71, 84)

A supportive, flexible childrearing structure encompasses several aspects such as:

- enough daily routine in the child's life;

- encouragement, stimulation and instruction to the child and the requirement of realistic demands;

- rules, limits, instructions and insight into the arguments for these rules;

- control of the child's behaviour; 
- enough space for the child's own wishes and thoughts, enough freedom to experiment and to

- negotiate over what is important to the child;

- no more responsibilities than the child is capable of handling (in this way the child learns the

- consequences of his behaviour within the limits which the parents or careproviders have set).

5. Adequate example set by parents (Art. 10, CRC; GC 14 paras. 70, 71, 84)

The parents or care-providers offer the child the opportunity to incorporate their behaviour, values and cultural norms that are important, now and in the future.

6. Interest in the child (Art. 31, CRC; GC 14 paras. 70, 71, 84)

The parents or care-providers show interest in the activities and interests of the child and in his perception of the world.

\section{Family: Future and Past}

7. Continuity in upbringing and care, future perspective (Arts. 5, 6, 9, 10, 18 CRC; GC 14 paras. $65,66,67,70,72,74,84)$

The parents or care-providers care for the child and bring the child up in a way that attachment bonds develop. Basic trust is to be continued by the availability of the parents or care-providers to the child. The child experiences a future perspective.

\section{Society: Current Situation}

8. Safe wider physical environment (Arts. 33, 34, 35, 36, 37 CRC; GC 14, paras. 70, 71, 73, $74,77,78,84)$

The neighbourhood the child grows up in is safe, as well as the society the child lives in. Criminality, (civil) wars, natural disasters, infectious diseases etc. do not threaten the development of the child.

9. Respect (Arts. 2, 13, 14, 15, 16, 30, 37 CRC; GC 14, paras. 56, 70, 73, 74, 79, 84)

The needs, wishes, feelings and desires of the child are taken seriously by the child's environment and the society the child lives in. There is no discrimination because of background, race or religion.

10. Social network (GC 14, paras. 70, 73, 84)

The child and his family have various sources of support in their environment upon which they can depend. 
11. Education (Arts. 17, 28, 29, 31 CRC; GC, 14 paras. 70, 71, 73, 79, 84)

The child receives a suitable education and has the opportunity to develop his personality and talents (e.g. sport or music).

12. Contact with peers and friends (Art. 31, CRC; GC 14, paras. 70, 73, 84)

The child has opportunities to have contacts with other children in various situations suitable to his perception of the world and developmental age.

13. Adequate examples set by the community (Arts. 2, 8, 13, 14, 15 CRC; GC 14, paras. 70, $73,84)$

The child is in contact with children and adults who are examples for current and future behaviour and who mediate the adaptation of important societal values and norms.

\section{Society: Future and Past}

14. Stability in life circumstances, future perspective (Arts. 6, 9, 10, 20 CRC; GC 14, paras. $65,70,74,84)$

The environment in which the child is brought up does not change suddenly and unexpectedly. There is continuity in life circumstances. Significant changes are prepared for and made comprehendible for the child. Persons with whom the child can identify and sources of support are constantly available to the child, as well as the possibility of developing relationships by means of a common language. Society offers the child opportunities and a future perspective. 


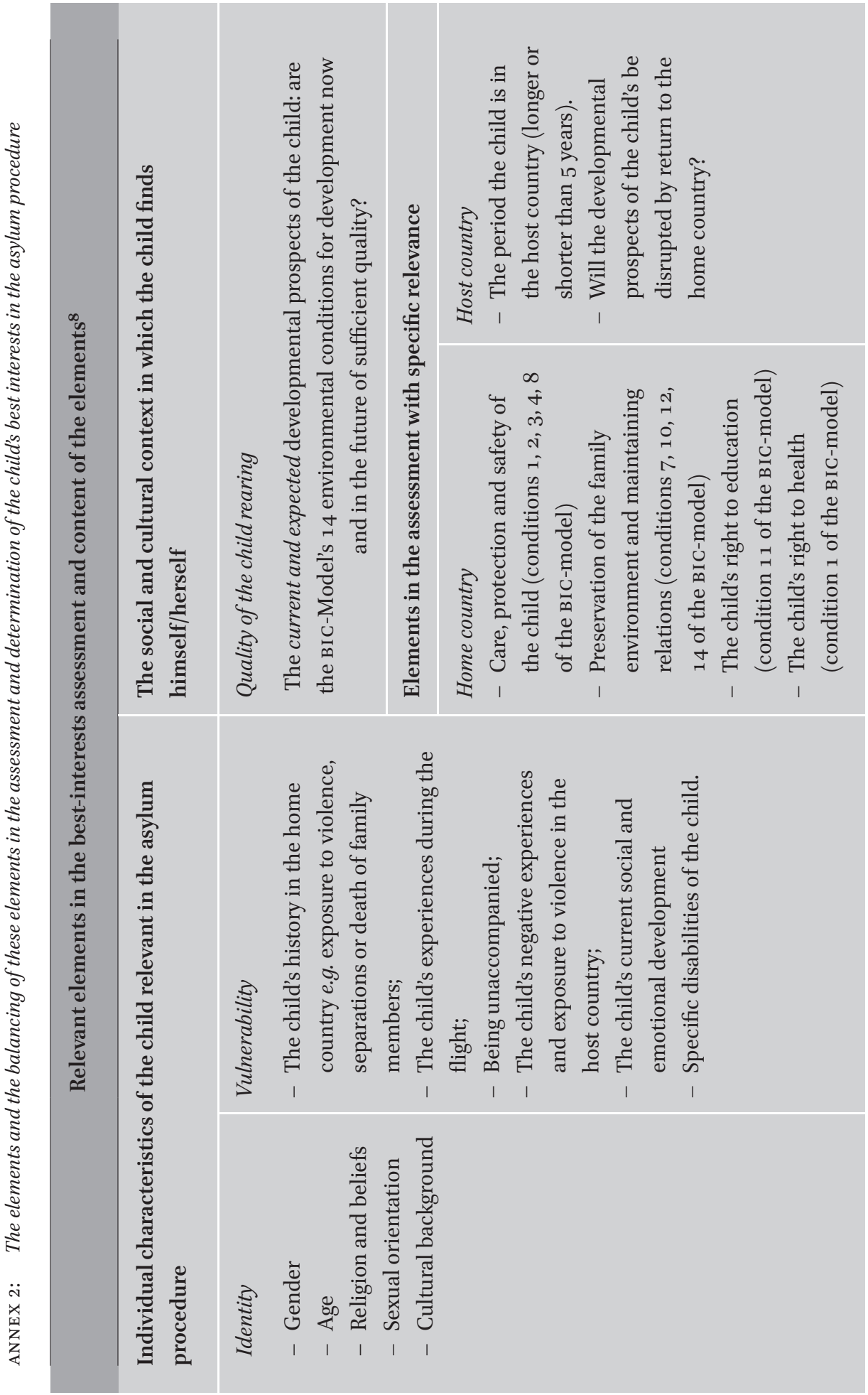




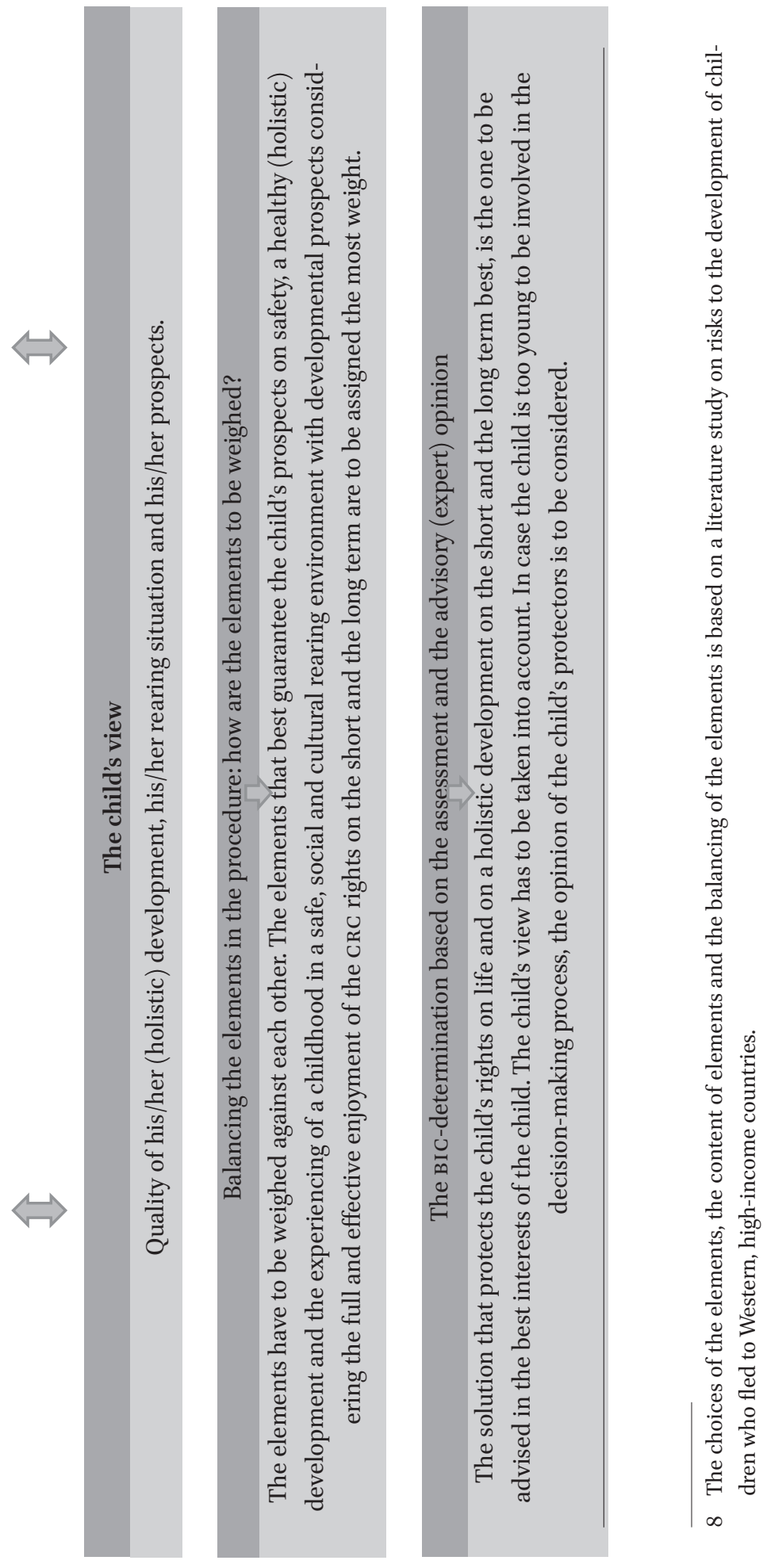

